\title{
Lexical reduction in German SMS communication
}

\author{
O. Bezzubova, S. Moiseienko
}

National Technical University of Ukraine "Igor Sikorsky Kyiv Polytechnic Institute”, Kyiv, Ukraine

Corresponding autor. E-mail: abezzubova@gmail.com, moyseyenko@bigmir.net

Paper received 26.03.19; Accepted for publication 05.04.19.

\section{https://doi.org/10.31174/SEND-Ph2019-194VII58-03}

\begin{abstract}
This article intends to tackle the problem of lexical reduction realisation in German SMS communication. In line with the recent events, whereby the transfer of information seems to take centre stage in society, there has been an increased usage of short forms and short texts commonly referred to as SMS messages. SMS message is a modern electronic-written form of speech interaction. In the research carried out $10 \%$ of the researched texts contained lexical reduction. This includes graphical and lexical abbreviations, acronyms, letter-digital shortenings and syncope. The findings also highlighted that there was substantive usage of graphically shortened meaningful units accepted in literary German. Moreover, the studies found out that a peculiar feature of abbreviation in German texts of SMS messages is shortening of separate words, as well as complete word combinations, and sentences that are actualized in conversational speech. Another feature that came to the limelight is letter-digital shortenings whereby a digit is used in place of the word or word part parts of the word are laterally represented in private German SMS communication. As a result of the informatization of society syncope, namely syncope and apocope, have become productive means of word-formation. Thus, shortening of proper names, names of organizations, establishments, countries and cities have become part and parcel of German SMS communication. Aphaeresis, however, is rarely encountered in German SMS communication.
\end{abstract}

Keywords: SMS communication, lexical reduction, shortening, acronyms, syncope, apocope.

Introduction. In the XXI century, electronic communication came to dominate in the process of ensuring interrelation and cooperation of social persons. Information communication activity of the modern society is increasingly connected with the system of electronic communication that changed the format, time and spice dimensions of social communications. SMS communication that differs greatly from other forms of electronic communication by its way of presentation and expression reflects technological and public processes in their social dynamics [12, p. 29].

Text messaging has a distinct pattern in terms of lexical, syntactic and typographical forms that fulfil young people's needs as well as providing for new technology. The language of texting has its own style, and the dominant features in SMS language are the use of abbreviations, slang, syntactic reductions, asterisk emoting, deletion of parts of speech, especially subject pronoun, preposition, articles, copula, auxiliary or modal verbs and contractions. The language of texting has features from both the written and spoken forms and Crystal suggests that SMS language is more than just a hybrid of speech and writing which must be seen as a new species of communication called 'a third medium'. SMS is quiet unique with regards to language selection since it resembles the written form of speech which is interactive and dependant on shared space, time and background knowledge. Like normal speech, text messages are structurally simple, fragmented, concrete and conditional on situation $[14, \mathrm{p}$. 156].

Since the first message was sent in 1990, we have witnessed an explosion of Short Message Service (SMS) use. In 2011, approximately 7.8 trillion SMS messages were sent around the globe. While younger people (adolescents and young adults) appear to be the most avid SMS users, this new way of communicating and socializing has been adopted by people of all ages working in all kinds of professions and with all levels of education [15, p. 260]. SMS communication takes place in different role constellations - in teenage clique, among members of the Bundestag, in SMS church services [11, p. 53]. SMS messag- es are effectively used in the work of EU special operations services: police, gendarmerie, fire brigades, rescue services, etc. In the modern world of constant threats and dangers, the time of information transfer and the speed of response to extreme situations are reduced to a second. The use of SMS messages enables emergency services to report on emergency situations in a relatively short period of time, create response plans and neutralize them.

Either in speech activity or any other activity, people tend to find the ways of its effective fulfilment and reduction of applied efforts [6, p. 77]. The language development within the last decades is characterized by general feature - compression. This phenomenon is connected to social reasons: first and foremost, the acceleration the pace of life, the extension of language contacts field as well as other social phenomena have contributed to the same. Compression is performed on the language by means peculiar for its grammatical structure - its phonetics, semantics, grammar and lexis [4, p. 343].

The conciseness of texts is the characteristic feature of SMS communication: the number of signs is limited, it makes the author to concentrate on the most important aspects of his message and influences linguistic-stylistic features of communication, subjecting the utterance to the principles of economy [13, p. 935]. What is more, written language in the field of SMS communication is characterized by the adaptation of the speech language means, which include speech language means, to written form with the help of paralinguistic means. This compressed virtual genre economizes on the senders effort and time in that it does not encourages description; a feature that is peculiar to traditional written language. This descriptive feature partially compensated for the absence of paraverbal means. New language patterns in SMS communication (language material processed by language means for creation of language signs) are connected with high level of interactivity, manipulative capability, multimedia and operational efficiency [8, p. 55].

The study of German SMS messages in linguistics is connected with the following names of national and international linguists as M. A. Aakhus, J. E. Katz, P. 
Schlobinski, J. Schwitalla. Linguistic peculiarities of German SMS messages are thoroughly investigated in scientific works of J. Androutsopoulos, K. Dürscheid, N. Döring, T. Sievel, A. V. Palkova, P. Schlobinski, G. Schmidt analyze communicative characteristics of German SMS messages.

Thus, thematic justification of the research of German abbreviations and shortenings is identified by the major popularization of these new language patterns of word formation in modern German SMS communication.

The purpose of this article is to investigate the factors of these lexical units formation, their peculiarities in the German language as well as their classifications of such word formations in the German SMS communication.

To do that, the article had the following objectives:

- to identify the factors that influence the appearance of German abbreviations and shortenings in SMS messages;

- to investigate these lexical units formation peculiarities in German languages;

- to establish the most productive types of such word formation in German SMS communication.

Results and discussion. On a microlinguistic level, the prevailing tendencies of SMS messages are a reduction, which is attributed both to technical restrictions of the medium and to be conceptually spoken character of its use, and creative language use, drawing on and playfully combining a wide range of linguistic resources [11, p. 49]. SMS communication is a productive place for lexical reduction realization. Out of the 231 text messages investigated, $10 \%$ of the texts were found to have applied the concept of lexical reduction. SMS messages commonly apply the expression plane reduction. This includes the use of short forms, which is normally a means of saving on characters in the unique conditions of communication. The appearance of these shortened units is as a result of the society's need to pass a great deal of information within the time unit [1, p. 4].

Private German SMS messages of the body were chosen by continuous sampling method from earlier uninvestigated free access German Internet webpage smsvongesternnacht.de.

Shortening as a means of enriching the German vocabularies occurs in different ways and structural types. Within the private SMS communication the shortenings are characterized by abbreviations, acronyms and apocopes. Abbreviation for example is the process of secondary nomination unites formation with the status of a word that involves apocopes of any linear parts of motivation sources and as a result leads to the introduction of such a word that in its form reflects the end part or parts of outgoing motivation unit [10, p. 66]. Introduction of abbreviation as a special way of word formation aimed at the creation of shorter word combinations or compounding in comparison with outgoing ones, synonymic to their nominations [5, p. 3]. Traditionally abbreviations are mostly classified into two groups, namely: graphical and lexical abbreviations.

Graphical abbreviations. Graphical abbreviations refer to the abbreviations that are only used in written speech and do not have a personal sound form. In the verbal speech, they are realised as a corresponding nonshortened form [10, p. 66]. The majority of graphical abbreviations actualized in English and German SMS messages are conventional: Eng. $b-$ be, $c-$ see, $r-$ are, $u$ - you; German $h$ - Uhr, $u$ - und, PS - Postskriptum, z.B. - zum Beispiel (z.b., $z b$ - graphical abbreviations in SMS communication). For example: bleib heute zu hause. hab versucht beyonce nachzutanzen $\boldsymbol{u}$ mir irgendwas ausgerenkt.

Shortened English forms are - r, you - u, German und $-u$, which are used by SMS communicants, are the result of meaningful graphically shortened units accepted in literary English and German.

Lexical abbreviations. As the result of lexical shortening and abbreviation, a shorter nominative unit appears in comparison with the outgoing unit. The material of the research shows the usage of abbreviations by Germanspeaking communicants - nouns, created from the initial letters, initial elements of a compound word, word combination or phrase. Fixed in the modern vocabulary shortenings belong to such conventional shortenings: Wörterbuch der Abkürzungen Duden abbreviation shortenings, as der Bhf - der Bahnhof, die EM - die Europameisterschaft, die FH - die Fachhochschule, der Hbf - der Hauptbahnhof, die Nr. - die Nummer, die OP - die Operation, die Std. - die Stadt, die VWL - die Volkswirtschaftslehre, die $W G-$ die Wohngemeinschaft. For example:

Freimittag zur Fh zu laufen fühlt sich einfach falsch an $\therefore$

Verdammt... erster tag in der $\boldsymbol{w g}$ und das studentenleben hat mich fest im griff: mein abendbrot war ein zerbrochener butterkeks -.-

Despite for its formal codification, the reduced word saves the same internal structure as the outgoing word that means that it indicates the same denotation. But the shortened form may add connotative pattern to it $[3, \mathrm{p}$. 94] and raise the expressiveness of the SMS message text. Shortening and simplification of multi-syllable nominative units due to the form stipulate constant supplementation of English and German with new units. Some substitutes of multi-syllable units that function in German SMS messages that have not completely undergone the step of lexicalization: abbreviations das $K h / K H$ - das Krankenhaus, das WE - das Wochenende, der WSV - der Winterschlussverkaufare not fixed in German vocabularies. For example, German SMS dialogue where das WE is the key unit:

- Heii omg ich hab mir gerade so geile schuhe gekauft

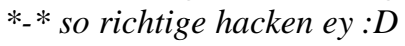

Lieg im $\boldsymbol{k h}$ hab mir den Fuß gebrochen -.-

$-x D$

The distinctive feature of abbreviation in the texts of English SMS messages is shortening of not only separate words but full word combinations and sentences frequently used in written speech as well, for example: $A S A P$ - As soon as possible, $B B S$ - Be back soon, $B F N-$ Bye for now, $B T W-$ By the way, $G L-$ Good Luck, $H \& K-$ Hugs and Kisses, $I C$ - I see, $I L U$ - I love you, IMO - In my opinion, $I O W$ - In other words, $L O L$ - Laughing out loud, TIA - Thanks in advance etc.

In the German context, the speakers often use different forms of saying good bye: good bye form from official mailing $M f G$ - Mit freundlichen Grüßen, Internet communication $C U-$ See you and private mailing $L G / L g-$ 
Liebe Grüße, ILD - Ich liebe dich, $H D L$ - Hab dich lieb, $L D$ - Liebe dich, built under the principal of abbreviation. For example: Anni

- Hi Mama. Wie klappt's mit dem neuen Laptop? lg

- Hi Anni. Komm gut klar. Nur mit dem Internet habe ich noch Probleme. Ich habe gerade mein E-Mail Password bei Google eingegeben. Lg Mama

A separate group of shortened lexical texts is known as an acronym. Acronyms are considered as a type of initial abbreviations pronounced as words written by the same letters [2, p. 189]. Acronyms are shortened words formed from the initial letters or initial elements of the word combination words either similar or the same form (phonetic structure) with the common word [9, p. 15]. Among the acronyms found in the German short messages are shortened lexical units of English origin such as: die IT die Informationstechnologie, das HIV - das Humane Immundefizienz-Virus, die SIM - die Subscriber Identity Module, VIP - Very Important Person. The study also came across acronyms of German origin like der ZOB der Zentraler Omnibus-Bahnhof. For example: Mir geht es gut! Bin beim ZOB, betrunken, bald zu Hause.

Another aspect of shortenings that was looked into during the study is letter-digital shortenings. Letter digital shortenings, simply put, refer to the phenomenon whereby a digit is used in place of a word or even part of the word. This means that the phonetic formalization of the digit coincides with the words, this mode of shortening is however less common in private SMS communication. For example, explication case in the act of German SMS communication of the noun Nacht in the form of latterdigital abbreviation $n 8$ :

- weißt noch wie es war gestern $\mathbf{n 8}$,was du alles gesagt hast..?

- hmm ich war voll babyyy

- gut dann klär ich dich auf... du hast gesagt ficK mich Ich bin deine schlampe XD

Letter digital abbreviations of the mode of saying goodbye ,gn8“ and its expanded variant gute n8, were borrowed by the German SMS communication from the Internet communication. For example:

- Ich bin zuhause .... Schatz mach dir keine sorgn ich bin doch bin

- boa, ich hoffe du liegst alleine im bett!!!

- ich bin bi gute $\mathbf{n 8}$

Mathematical symbols have also not been left out and they occupy a special place in the modern day short messaging arena. This place denotes the closeness between mathematical and computer discourse abbreviations: 2 to, 4 - for, $2 B$ - to be, $B 4$ - before, $F 2 F-$ Face to face etc. Due to the influence of the internet and other emerging new forms of communication, language is being revolutionized and supplemented by new lexical units. These new lexical units have become the acceptable language symbols of the time.

To satisfy the society's needs in new compressed names in private German SMS communication shortening (reduction) of the word stem is applied as the means of word formation and word creation which serves to save language units.

Word stem reduction can be further classified into the following categories: apocope (reduction of the stem final part): semi (from semicolon), param (from parameter); syncope (word middle reduction): char (from character), doc (from document), app (from application) and aphaeresis (initial word part reduction, mainly of unstressed vowels): Net (from Internet), mend (from amend) [7, p. 83].

As a result of the research carried out, a conclusion was drawn that apocope is one of the most productive abbromorphemic reduction types applied in the English and German languages.

Different conventional, i.e. nontechnical reductions formed by apocope that find their way into the German SMS communication include different functional units like: general literary names of the week days - der $D i$, der $S a$; terminological noun der Akku; colloquial words nouns die Info, die Geschi, die Min., das Navi, der Pulli, die Quali, die Uni and adjectives bi, ok; slangisms die Demo, das Deo; school and student slangisms das Abi, die Mathe, der Prof; jargonisms der Alk, der Teenie just to highlight a few. For example:

- Ich bin jetzt von der Autobahn runter. Ich hoffe das wenigstens das Navi weiß was es macht. (-)

- Du fährst einen Mini, ein Engländer der von Bayern entwickelt wurde. Wir sehen uns Weihnachten

German SMS communication is also characterized by the reduction of the final parts of the word stem. These reductions have contributed the increase in usage of these shortenings in the written communication. The shortenings in question include examples such as: $b$ - preposition bei, Bib/ BIB - noun die Bibliothek, eig - adjective eigentlich, viell - particle vielleicht, $G$ - noun die Gruppe, $i$ - personal pronoun ich. In most cases the meanings of these reductions are deduced within the context in which they are used, for example: Fиииииииииииииисk! Im Büro eingepennt und vom Hausmeister geweckt worden .- ich hab eig nix gegen die Frühschicht, wenn sie denn nicht immer so früh wär:S ich geh erstmal weiter pennen $: D$

The lexical unit nix, used when texting, as well as net and ned are widespread variations of the negative pronoun nichts. These variations can be traced from internet communication and are affiliated to computer jargon.

The reduction in usage of the German personal pronoun ich in the short message communication, increases its chances of becoming a conventional reduction, for example: $\boldsymbol{i}$ hab nämlich festgestellt, dass $\boldsymbol{i}$ garnet disziplinlos bin beim essen, sondern, dass essen mi willenlos macht. also kann $\boldsymbol{i}$ nix dafür!! und wenn doch, dann bin $\boldsymbol{i}$ trotzdem verdammt wahnsinnig diszipliniert weil $\boldsymbol{i}$ nämlich nur ganz konsequent des ess was fett macht, und grundsätzlich nix unter doppelter menge!!

The speaker repeatedly reduces personal pronoun ich $\rightarrow i$ and its accusative form mich $\rightarrow m i$.

The reduction of SMS communicants' names and conversation objects to initial letter, which is conceptually motivated phenomenon constitutes independent category of special reduced shortenings found out herein in the SMS messages. For example:

- H. trinkt eh nur ein Glas sekt

- dann kann sich $\boldsymbol{h}$. aber wenigstens an den Abend erinnern und hat am nächsten morgen nicht mehr abbekommt!

- dann kann sich $\boldsymbol{h}$. aber wenigstens an den Abend er- 
innern und hat am nächsten morgen nicht mehr abbekommt!

A mutual apperceptional basis of the speaker's and addressee's SMS communication makes it possible for proper names, names of organizations, countries and cities shortenings to successfully function within communication act. The following SMS message text illustrates the case of the city name reduction in German SMS communication - initial letter $M$ is the shortened form of city name Magdeburg: $U m$ 10.00 bin ich in $\boldsymbol{M}$.

Shortening is a widespread way of new words formation. Syncope is a productive type of abbromorphemic reduction. Shortened units formed with the help of syncope have conversational and slang pattern, marking the speaker's affiliation with a certain group. Reduced noun die Tanke founded in the following dialogue in German is the usual unit that coexists collaterally with a derivative word - noun die Tankstelle, but it differs from it by its conversational sphere of use and conversational pattern: Ist es normal, dass ich mir jeden Tag an der Tanke neue Kippen kauf, nur um mich mit den Kassierern zu unterhalten? Hab jetzt schon 4 ungeöffnete Packungen daheim...

In German by means of middle reduction nouns, adverbs are shortened (irgendwo $\rightarrow i$ wo, irgendwer $\rightarrow i w e r$, irgendwann $\rightarrow$ iwann) and verbs (telefonieren $\rightarrow$ telen). For example:

- Lass mal telen

- Ne, ich sehe heute scheiße aus!

To express the offer to communicate on the telephone the speaker uses conversational verb telen formed by means of middle reduction in the text of SMS message.

A special layer of reduced units in German is constituted by English units - nouns Handy $\rightarrow$ das Hdy, Birthday $\rightarrow$ der Bday and exclamation sorry $\rightarrow$ sry. For example: Hey Schatz, schonmal alles Gute zum Bday. Bin in der Stadt, wollte dir dein Geschenk holen, aber der eine Laden hatte schon zu in dem anderen habe ich Hausverbot; SRY. Soll ich Pommes mitbringen

The speaker congratulates the addressee with his birthday for which identification he uses reduced English noun Bday in the text and apologizes for his present by means of graphically emphasized English exclamation $S R Y$.

The word's middle reduction is peculiar mainly in written speech. Aphaeresis as the next category of reduced lexical units' formation that functions in verbal speech takes place more frequently rather than apocope and syncope. As a single case of aphaeresis actualization we hereby give the following act of dialogue of German SMS communication in the text of reaction SMS message where adjective okay was initially reduced to kay:

- Ich weiß nicht was das zwischen uns ist, hab ich das Gefühl wir müssen reden.. was meinst du?

- Jaa denk ich auch.Am besten jeder sagt mal was er so für den anderen fühlt und was er für ihn empfindet ... kay?

\section{- Du fängst an:D!}

Realization of syncope and aphaeresis combination is common in German SMS communication in the form of specific reduction of adjective eigentlich $\rightarrow$ eigtl and particle vielleicht $\rightarrow$ vll or vlt. For example:

haha ich muss dir was erzähle hdl und vll au mehrwow was heiss denn des? "und mehr!" grrrrr =D KUSS

vll steh ich auf dich...

In both SMS message texts, the speaker uses reduced particle $v l l$ that identifies gradual explicit declaration of love. Electronic SMS communication with principals of written speech is the place of realization of such type of reduced words. Convenience in writing, the economy of language units and meaningful capacity are the reasons of reduction popularity. Reduced word form saves time and often lets pass more information [7, pp. 82-83].

Conclusion. In private German SMS communication, the reduction of different language levels is subordinated not only for time saving and communicative space place but also it is a highlighter of the SMS message text tonality. The SMS message specific is in the communicants' imitation of verbal speech and conversation in writing. SMS communication removes the borders between verbal and written forms of communication. This is ascertained by the appearance of a new forms of speech interaction written conversational language which is characterized by shortened units that provide that transfer of a great deal of information within a short period of time. This way of vocabulary supplementation is represented by the following structural types: graphical and lexical abbreviations, acronyms, letter-digital shortenings and reduction.

The research carried out highlighted the fact that during the communication process the participants not only make use of conventional shortenings of separate words (mainly nouns); but also of phrases and sentences. This occurs both in the German communication process. Moreover, the findings of the result attested to the fact that letter digital shortening does not take place to a large extent in the private SMS communications. With the expansion of language contact spheres in the electronic space of communication, word stem reduction methods such as apocope and synocope as the productive types of word stem reduction have played a key role in German language. Thus the shortening of proper names, names of establishments, organizations, countries and cities have become a feature in German SMS communications. Apharesis, on the other hand, is found to be more common in verbal communication as opposed to German SMS communication.

Nonverbal means of communication used in electronic messages seem to be another viable area of research due to the fact, that they are mostly used to compensate the absence of the direct visual contact between the participants of electronic communication, and influence the verbal base of such communication as well. 


\section{REFERENCES}

1. Алексеева Н. Н. Типология сокращенных лексических единиц в современном английском языке: дис. ... канд. филол. наук: 10.02.04 / Н. Н. Алексеева. - Москва, 1984. $24 \mathrm{c}$.

2. Арнольд И. В. Лексикология современного английского языка: учеб. пособие / И. В. Арнольд. - 2-е изд., перераб. - М.: Флинта: Наука, 2012. - 376 с.

3. Снікєєва С. М. Скорочення слова як механізм формотвоM. Єнікєєва // Вісник Житомирського державного університету імені Івана Франка. - Житомир: Вид-во ЖДУ ім. І. Франка, 2006. - Вип. 27. - С. 93-96.

4. Златоустова Л. В. Компрессия и ее связь с фонетическим и грамматическим строем языка / Л. В. Златоустова // Русский язык: исторические судьбы и современность: труды и материалы III Международного конгресса исследователей русского языка, 20-23 марта 2007. - М.: МГУ им. М. В. Ломоносова, 2007. - С. $343-344$.

5. Лопатин В. В. Аббревиатура / В. В. Лопатин // Лингвистический энциклопедический словарь. - М., 1990. - С. 3.

6. Мамалига А. І. Синтаксис тексту / А. І. Мамалига // Нариси про текст: теоретичні питання комунікацій і тексту. К.: РВЦ «Київський університет», 1998. - С. 66-221.

7. Мартос С. А. Усічення основи як спосіб творення молодіжного сленгу / С. А. Мартос // Ученые записки Таврического национального университета им. В. И. Вернадского. Філологія. - Т. 18 (57). - № 2. - Симферополь: ТНУ им. В. И. Вернадского, 2005. - С. 82-84.

8. Мойсеєнко С.М. Прагмасемантичний та прагмастилістичних аспекти сучасного англомовного наукового комп'ютерного дискурсу: дис. на здоб. наук. ступ. канд. філол. наук: 10.02.04 / Мойсеєнко С.М.; Запор. нац. ун-т. - Запоріжжя, 2014. - 262 c. рення та словотворення в сучасній англійській мові / С.

9. Нелюбин Л. Л. Толковый переводоведческий словарь / Л. Л. Нелюбин. - 3-е изд., перераб. - М.: Флинта: Наука, 2003. $-320 \mathrm{c}$.

10. Палкова А. В. Аббревиация как способ образования новых лексических единиц в сфере компьютерной техники и Интернета / А. В. Палкова // Иностранные языки в экономических вузах России: всероссийский научноинформационный альманах. - Спб.: Издательство СанктПетербургского государственного университета экономики и финансов, 2004. - С. 66-80.

11. Androutsopoulos J. SMS-Kommunikation: Ethnographische Gattungasnalyse am Beispiel einer Kleingruppe / J. Androutsopoulos, G. Schmidt // Zeitschrift für Angewandte Linguistik. - 2002. - № 36. - S. 49-79.

12. Bezzubova O. O. Syntactic organization of German SMS texts / O. O. Bezzubova // Journal of the National Technical University of Ukraine «Kyiv Polytechnic Institute»: Philology and Educational Studies. - 2016. - № 8. - pp. 29-33.

13. Bezzubova O. O. Phonetic stylistic peculiarities of political German Twitter communication / O. O. Bezzubova, L. S. Ivashkevych, A. Lange // Educational Researcher. - 2017. № 9(2), pp. 935-947.

14. Kahari L. Language of Texting, Patterns and Factors of Language Choice in Text Messaging of University of Zimbabwe, Shona-English Bilinguals/ L. Kahari // International Journal of Humanities and Social Science. - 2014. - 4(1), pp. 156-163.

15. Morel E. SMS communication as a plurilingual communication. Hybrid language use a challenge for classical codeswitching categories / E. Morel, C. Bucher, S. Pekarek Doehler, B. Siebenhaar // Linguisticae Investigationes. - 2012. 35(2), pp. 260-288.

\section{REFERENCES}

1. Alekseyeva, N. N. (1984). Tipologiya sokrashchennyh leksicheskih edinic v sovremennom anglijskom jazike [Typology of shortened lexical units in modern English], Moscow, Russia.

2. Arnold, I. V. (2012). Leksikologiya sovremennogo anglijskogo jazyka [Lexicology of modern English]. Moscow, Russia.

3. Ienikeeva, S. M. (2006). Skorochennia slova jak mehanizm formotvorennia ta slovotvorennia v suchasnij anglijskij movi. [Word shortening as a mechanism of from creation and word formation in modern English]. Zhytomyr, Ukraine.

4. Zlatoustova, L. V. (2007). Kompressija i eje sviaz' s foneticheskim i grammaticheskim strojem jazyka [Compression and its connection with phonetic and grammar language structure]. Moscow, Russia.

5. Lopatin, V. V. (1990). Abbreviatura [Abbreviation]. Linguistic encyclopedia vocabulary. Moscow, Russia.

6. Mamalyga, A. I. (1998). Syntaksys tekstu [Syntax of a text].
Kyiv, Ukraine.

7. Martos, S. A. (2005). Usichennia osnovy jak sposib tvorennia molodijnogo slengu. [Reduction of stem as a means of youth slang creation]. Simferopol, Ukraine.

8. Moiseienko, S. M. (2014). Pragmasemantychnyj ta pragmastylistychnyj aspekty suchasnogo anglomovnogo naukovogo komp'juternogo dyskursu [Pragmasemantic and pragmastylistic aspects of modern English scientific computer discourse]. (Extended candidate's thesis). Zaporizhzhia. Ukraine.

9. Neliubin, L. L. (2003) Tolkovyj perevodovedcheskij slovar' [Definition translation dictionary]. Moscow, Russia.

10. Palkova, A. V. (2004). Abbreviacija kak sposob obrazovanija novyh leksicheskih edinits $\mathrm{v}$ sfere komp'juternoj tehniki I Intrneta [Abbreviation as a means of creation of new lexical Petersburg, Russia. units in the sphere of computer technique and Internet]. Saint- 